УДК 796.912:793.3

DOI: $10.31866 / 2616-7646.3 .2 .2020 .220540$

\title{
РОЛЬ ХОРЕОГРАФА У ФІГУРНОМУ КАТАННІ НА КОВЗАНАХ
}

\author{
Ситченко Катерина Володимирівна, \\ викладачка, \\ Харківська державна академія фізичної культури, \\ Харків, Україна, \\ https://orcid.org/0000-0003-2807-1356, \\ oxyd2011amail.ru
}

Мета статті - виявити роль хореографа в роботі зі спортсменами фігурного катання на ковзанах. Методологія. Історико-хронологічний підхід, метод мистецтвознавчого аналізу виступів фігуристів, порівняльний метод забезпечили проведення дослідження. Наукова новизна. Вперше акцентовано увагу на ролі хореографа в підготовці спортсменів фігурного катання на ковзанах та створенні спортивних програм для них. Висновки. Художній ефект виступу у фігурному катанні на ковзанах, що досягається красою і гармонійністю рухів, за умови їх органічної єдності з музикою, забезпечується значною мірою хореографом, який створює танцювальне тло спортивної композиції, забезпечує поєднання художнього і спортивного. На озброєнні у хореографа спортивних програм весь спектр різновидів, напрямів та стилів хореографічного мистецтва. Важливою рисою створюваних композицій $\epsilon$ естрадність, що передбачає яскраве розкриття індивідуальності виконавців. Для створення індивідуального танцювального стилю спортсменів-фігуристів необхідні довготривалі, систематичні заняття упродовж років. Робота хореографа з підготовки фігуристів вимагає поєднання традиційних для танцювального мистецтва методів та форм роботи зі специфічними спортивними вимогами (екзерсис біля станка та на середині залу, адаптований для досягнення максимальної користі для фігуристів, зокрема, на вузькій опорі). При розробці музичного супроводу для виступу хореограф повинен брати до уваги психофізичні особливості та емоційні можливості окремого виконавця, пари або групи спортсменів, адже спортсмени різною мірою можуть володіти найрізноманітнішими амплуа (героїчного, романтичного, драматичного, комічного та ін. характеру). Хореографу варто також бути обережним з використанням для спортивних композицій музичних фрагментів з балетних вистав, де композитор створює образ філософського звучання.

Ключові слова: хореограф; фігурне катання на ковзанах; техніко-естетичні види спорту; танець. 


\section{РОЛЬ ХОРЕОГРАФА В ФІГУРНОМ КАТАНИИ НА КОНЬКАХ}

\author{
Ситченко Екатерина Владимировна, \\ преподаватель, \\ Харьковская государственная академия \\ физической культуры, \\ Харьков, Украина, \\ https://orcid.org/0000-0003-2807-1356, \\ oxyd2011amail.ru
}

Цель статьи - выявить роль хореографа в работе со спортсменами фигурного катания на коньках. Методология. Историко-хронологический подход, метод искусствоведческого анализа выступлений фигуристов, сравнительный метод обеспечили проведение исследования. Научная новизна. Впервые акцентировано внимание на роли хореографа в подготовке спортсменов фигурного катания на коньках и создании спортивных программ для них. Выводы. Художественный эффект выступления в фигурном катании на коньках, который достигается красотой движений, при условии их органического единства с музыкой, обеспечивается в значительной мере хореографом, создающим танцевальный фон спортивной композиции, обеспечивающим сочетание художественного и спортивного. На вооружении у хореографа спортивных программ весь спектр разновидностей, направлений и стилей хореографического искусства. Важной чертой создаваемых композиций является эстрадность, что предполагает яркое раскрытие индивидуальности исполнителей. Для создания индивидуального танцевального стиля спортсменов-фигуристов необходимы долговременные, систематические занятия годами. Работа хореографа по подготовке фигуристов требует сочетания традиционных для танцевального искусства методов и форм работы со специфическими спортивными требованиями (экзерсис у станка и на середине зала адаптирован для достижения максимальной пользы для фигуристов, в частности, на узкой опоре). При разработке музыкального сопровождения для выступления хореограф должен принимать во внимание психофизические особенно-

\section{ROLE OF THE COREOGRAPHER IN FIGURE SKATING}

\author{
Kateryna Sytchenko, \\ Lecturer, \\ Kharkiv State Academy \\ of Physical Culture, \\ Kharkiv, Ukraine \\ https://orcid.org/0000-0003-2807-1356, \\ oxyd2011amail.ru
}

The purpose of the article is to identify the role of a choreographer in working with figure skating athletes. Methodology. Historical and chronological approach, the method of the art analysis of the skaters' performances, a comparative method provided the study. Scientific novelty. For the first time, attention is focused on the role of the choreographer in the training of athletes in figure skating and the creation of sports programs for them. Conclusions. The artistic effect of performance in figure skating, which is achieved by the beauty of the movements, when they are organically united with the music, is provided to a large extent by the choreographer, who creates the dance background of the sport composition, providing a combination of artistic and athletic. The choreographer of sports programs is armed with a whole range of varieties, directions and styles of choreographic art. An important feature of the created compositions is variety, which implies a vivid disclosure of the performers' individuality. To create an individual dance style for figure skaters, long-term, systematic lessons are needed for years. The work of a choreographer in training figure skaters requires a combination of traditional dance techniques and forms of work with specific sports requirements (exercise at the bar and in the middle of the hall is adapted to achieve maximum benefit for the skaters, in particular, on a narrow support). When developing musical accompaniment for a performance, the choreographer must take into account the psychophysical characteristics and emotional capabilities of an individual performer, couple or group of athletes, because athletes to varying degrees can have a wide variety of roles (heroic, romantic, dramatic, comic, etc.). The choreographer should also be careful with the use 
сти и эмоциональные возможности отдельного исполнителя, пары или группы спортсменов, ведь спортсмены в разной степени могут обладать самыми разнообразными амплуа (героического, романтического, драматического, комического и др. характера). Хореографу стоит также быть осторожным с использованием для спортивных композиций музыкальных фрагментов из балетных спектаклей, где композитор создает образ философского звучания.

Ключевые слова: хореограф; фигурное катание на коньках; технико-эстетические виды спорта; танец. of musical fragments from ballet performances for sports compositions, where the composer creates an image of a philosophical sound.

Keywords: choreographer; figure skating; technical and aesthetic sports; dance.

Актуальність теми дослідження. Взаємодія хореографії й техніко-естетичних видів спорту, до яких належить і фігурне катання, є однією з актуальних проблем культурологічних, мистецтвознавчих та спортивних досліджень. Сьогодні загальноприйнятим стало розуміння необхідності залучення хореографії до змагальних та показових виступів фігуристів, до навчально-тренувального процесу. Важлива роль у цьому належить хореографу, роль якого недостатньо акцентована в спеціальних дослідженнях.

Аналіз останніх досліджень та публікацій. Різні аспекти розвитку фізичних якостей спортсменів-фігуристів було розкрито в працях I. Абсалямової (1983), І. Медведєвої (2002, 2014), М. Помелової та О. Тихомирова (1985), В. Рижкіна (Рыжкин, 1970), В. Тодорової (2018), В. Тихонова (1985) та ін. Ми також торкалися проблеми використання хореографічних елементів у танцях на льоду (Ситченко, 2018). Однак ролі хореографа в підготовці фігуристів та спортивних програм для них не було присвячено спеціального дослідження.

Мета статті - виявити роль хореографа в роботі зі спортсменами фігурного катання на ковзанах.

Виклад основного матеріалу. Більшість авторів праць 3 фігурного катання наголошують, що це - складнокоординаційний вид спорту, безпосередньо пов’язаний $з$ такими видами мистецтва, як музика, театр, хореографія, а тому вимагає від спортивних виконавців краси рухів, грації, пластики, витонченості й естетики катання. Науковці впевнені, що предметом змагання в цій спортивній дисципліні, особливим складом дій, способами ведення змагальної боротьби та видовищною естетикою, фігурне катання споріднене із сучасною культурою естетичного руху.

Художній ефект від змагального виступу спортсменів фігурного катання на ковзанах досягається не лише завдяки фізичним показникам, а й залученню принципів та лексики хореографічного мистецтва. Хореографічне тло спортивної композиції є тим об’єднуючим фактором, що забезпечує цілісність виступу спортсмена-фігуриста. I всі ці завдання для спортсменів вирішує професійний хореограф, адже тренер не володіє тим арсеналом танцювального мистецтва за- 
для максимальної реалізації художньо-естетичних аспектів підготовчого етапу, змагань та виступів.

Значне місце в роботі над змагальною програмою відведено естрадності. Насамперед, це виражається в характері спортивних програм і в тому, наскільки яскраво розкривається індивідуальність виконавців у цих композиціях. Саме хореограф покликаний виявити індивідуальність спортсмена художніми засобами.

До 2010 р. змагальна програма різних дисциплін фігурного катання містила три танці: обов'язковий, оригінальний та довільний. Оригінальний танець з'явився пізніше обов'язкового. Уперше він був показаний поза змагальною програмою дуетів із спортивних танців на льоду на Олімпійських іграх в Гренболі (Франція) в 1968 р. Кращим десяти танцювальним дуетам світу за пів року до початку Олімпіади було розіслано запрошення з детальним викладом правил і вимог до нового виду композицій. У день закриття спортивних ігор відбулася демонстрація оригінальних танців пасодобль і танго з оркестровим супроводом. 3 того моменту танцівникам щорічно рекомендували єдиний для всіх учасників ритм і темп оригінального танцю.

Починаючи із сезону 2010-2011 років, на міжнародній спортивній арені обов’язковий та оригінальний танці були об'єднані в один, так званий «короткий танцювальний номер». Саме він став поєднанням краси оригінального танцю та змагальної природи обов’язкового. Створення короткого танцю вимагає певних постановочних знань, пов’язаних із специфікою ковзанярських видів спорту. Так, приступати до роботи над коротким танцем варто лише після того, як спортсмени оволоділи арсеналом необхідних танцювальних рухів. За основу короткого танцю, переважно, беруть ті танцювальні елементи, які є обов’язковими для змагань. Серед них сучасні змагальні вимоги нараховують: серії твізлів (обертання в просуванні на одній нозі), доріжки кроків, підтримки, спільні обертання тощо.

Довільна програма становить собою хореографічні мініатюри тривалістю одна-дві хвилини, в кожній з яких демонструється щось принципово нове, своєрідне та вражаюче ефектне. Такою, наприклад, стала довільна програма 1994 р. «Showtune medley» - танцювальне попурі на музику сучасних джазових ритмів золотої медалістки в Ліллегаммері (Норвегія) українки О. Баюл. В основу виступу фігуристки було покладено елементи естрадної хореографії мюзик-хольного характеру; хореографу-постановнику льодового номера вдалося ввести в танцювальний текст імітацію рухів чечітки (Прес-служба відділення НОК України в Одеській області, 2019).

Наголосимо, що драматургічний зміст довільного танцю в парному катанні і танцях на льоду підсилюють такі важливі складники, як: оригінальність задуму і гармонійність рухів у повній відповідності із обраною музикою; чудова «скатаність» партнерів і синхронність виконання ними різноманітних елементів при зміні темпу й швидкості ковзання; демонстрація високої артистичності й досконалої музикальності; гранична насиченість програми складними елементами й комбінаціями таким чином, щоб фігуристи максимально використали всю площу льодового майданчика. Крім того, під час виконання довільного танцю спортсмени мають представити суддям і глядачеві відточену техніку ковзання на високій швидкості, точну відповідність рухів характеру музики. Довільний танець стає справжнім культурно-естетичним явищем і справляє найбільше позитивне 
враження тоді, коли обидва партнери складають єдине ціле й ведуть спільну та безперервну лінію руху. Незважаючи на суворі обмеження, уведені правилами Міжнародної федерації ковзанярів у програму одиночного й парного катання, специфіка довільного танцю є такою, що фігуристи постійно, використовують нові танцювальні прийоми, у пошуку яких їм допомагають фахівці 3 хореографічного мистецтва.

Естетичний ефект виконання довільного танцю в парному катанні й танцях на льоду досягається різними постановочними засобами. Наприклад, у парному катанні це - цілісний хореографічний фрагмент, де широко використовуються занадто часті роз'єднання партнерів, впроваджується значна кількість підйомів і підтримок, ковзань у позиціях «рука в руці», «боком один до одного», допускається паралельне й симетричне катання партнерів (Абсалямова, 1983, с. 19-21; Рыжкин, 1970, с. 15). Визнаним зразком такої програми став, наприклад, виступ українських спортсменів О. Назарової та М. Нікітіна на спортивній Універсіаді в 2017 р., де фігуристи отримали золоті нагороди змагання. В основу їхнього льодового номера було покладено симфонічну камерну музику виконавців Hugues le Bars (композиція «Sur mesure») та Raphael Beru (композиція «Diabolique»), а також використано елементи танцю контемп із складними підтримками в стилі танцю модерн (Український Форпост Спорту, 2017).

У довільній програмі танців на льоду основний естетичний акцент зроблено на синхронному катанні. Зазвичай вона складається з чотирьох хореографічних фрагментів, кожен з яких відрізняється характером виконання, має певний малюнок і в цілому виглядає закінченою художньою мініатюрою. Певні обмеження в довільній програмі для спортсменів, які виконують танці на льоду, зумовлені комплексом дозволених танцювальних рухів - різноманітних обертань, стрибків, підтримок, арабесків, піруетів. Приміром, допускається використання до п’ятьох арабесків, піруетів, підтримок та стрибків і не більше п’ятьох роз'єднань партнерів для зміни напряму руху танцю; зупинки, під час яких партнери демонструють різні пози, не можуть виконуватися довше, ніж два такти музичного супроводу тощо.

Вибір технічного матеріалу для довільної програми, зазвичай, зумовлений правилами змагань, проте важливого значення набуває не лише спортивна, а й художня сторона їх виконання. Найвдалішою вважається програма, яка містить велику кількість танцювальних рухів, різних за своїм характером, виконуваних 3 художньою та стилістичною однорідністю. Проте фахівці наголошують, що для створення індивідуального танцювального почерку спортсменів-фігуристів потрібні роки. Отже, принцип «від простого до складного»- займає в розробці довільної програми провідне місце (Рыжкин, 1970, с. 137).

Музиці у виступах спортсменів ковзанярських видів спорту техніко-естетичної спрямованості належить вирішальне слово. Від її вибору багато в чому залежить успішність спортивної програми. Саме музика формує художню платформу й диктує: бути чи не бути композиції виразною, емоційною, енергійною, чи матиме вона культурно-естетичний ефект. Обмежень стосовно вибору музичного супроводу відповідно до жанру хореографії, як правило, не існує. У виступах спортсменів тренер та хореограф-постановник висловлюють свої власні музичні смаки й побажання учасників змагань. При цьому вони враховують вікову категорію музичного твору. Адже, приміром, не має рації будувати виступ юної спортс- 
менки на музичному матеріалі, призначеному виражати складну гармонію зрілого жіночого образу. Крім того, варто враховувати, що будь-який музичний твір має емоційну заданість, зумовлену жанром і тематичним характером. Вибираючи музичний супровід для виступу, треба звертати увагу на психофізичні особливості окремого виконавця, пари або групи спортсменів, адже танцівники різною мірою можуть володіти найрізноманітнішими амплуа (приміром, героїчного, або, навпаки, романтичного, драматичного чи комічного характеру). Отже, хореограф має враховувати емоційні можливості учасників змагань.

Найвдалішим вибором для короткої та довільної спортивної програм $є$ невеликі музичні п’єси або інструментальні аранжування популярних мелодій. Нерідко при підборі музичного супроводу використовують і симфонічні форми - вони краще допомагають хореографії розкрити теми та образи, порушені в музиці. Це можуть бути інструментальні музичні твори, фрагменти з опер та ін.

Спостереження за сучасними змаганнями з ковзанярських видів спорту дають змогу з'ясувати, що постановники - тренери й хореографи - віддають перевагу творам 3 оригінальною драматургією та ритмічною структурою, яка має відповідати артистичним і темповим можливостям виконавців, їхній технічній і пластичній підготовленості.

Хореографу варто також бути обережним із запозиченням для спортивних композицій музичних фрагментів з балетних вистав, де композитор створює образ великого філософського звучання. Подібним шляхом насамперед ідуть доволі досвідчені спортсмени чи колективи, здатні зрозуміти й правильно інтерпретувати ці твори. Наприклад, відомо, що першими з виконавців ковзанярських техніко-естетичних спортивних дисциплін, які залучили до виступу музику великих класиків, стали Л. Білоусова й О. Протопопов. Саме вони в 1970-х роках використали в змаганнях на ковзанці твори Л. ван Бетховена і П. Чайковського. Вибір, зроблений фігуристами був порівнянний з діяльністю реформаторів балетної сцени, які в далекому минулому зламали традиційні уявлення про те, яку музику можна використовувати в театрі.

Кращому розумінню музично-пластичного образу сприяють ознайомлення спортсменів зі змістом музичного твору, історією його написання та прикладами інтерпретацій у хореографічних постановках. Для того, щоб пропонований музичний твір був доступним виконавцям, вони мають бути обізнаними з основами музичної грамоти. Зокрема, спортсмени повинні знати основні музичні поняття йтерміни - такт, ритм, тональність, розмір, акцент, тема твору та ін.

Елевація, стрибок і поза, одні з показників технічної майстерності у фігурному катанні на ковзанах, вимагають від спортсмена хореографічної підготовки, умінь та навичок, які забезпечує хореографічне навчання (традиційний балетний екзерсис біля станка та на середині залу). Заняття хореографією також сприяють розвитку артистизму, грації і кантиленності рухів (Рыжкин, 1970, с. 164-166).

Діяльність хореографа вимагає врахування і традиційних для танцювального мистецтва методів та форм роботи, і врахування специфічних моментів. Для набуття стійкості під час виконанні хореографічних елементів на льоду, зважаючи на маленьку площу опори леза ковзана, рекомендується виконувати танцювальні елементи на вузькій опорі, наприклад, на гімнастичній колоді (Рыжкин, 1970, c. 166-167). 
Наукова новизна. Уперше акцентовано увагу на ролі хореографа в підготовці спортсменів фігурного катання на ковзанах і в створенні спортивних програм для них.

Висновки. Художній ефект виступу у фігурному катанні на ковзанах, що досягається красою і гармонійністю рухів, за умови їхньої органічної єдності з музикою, забезпечується значною мірою хореографом, який створює танцювальне тло спортивної композиції, забезпечує поєднання художнього й спортивного компонентів. В арсеналі хореографа спортивних програм широкий спектр різновидів, напрямів і стилів хореографічного мистецтва. Важливою ознакою створюваних композицій є естрадність, що передбачає яскраве розкриття індивідуальності виконавців. Для створення індивідуального танцювального стилю спортсменів-фігуристів потрібні багаторічні систематичні заняття.

Робота хореографа стосовно підготовки фігуристів вимагає поєднання традиційних для танцювального мистецтва методів та форм роботи зі специфічними спортивними вимогами (екзерсис біля станка та на середині залу адаптований для досягнення максимальної користі для фігуристів, зокрема, на вузькій опорі).

При розробці музичного супроводу для виступу хореограф повинен брати до уваги психофізичні особливості та емоційні можливості окремого виконавця, пари або групи спортсменів, адже спортсмени мають різні навички в оволодінні найрізноманітнішими амплуа (героїчне, романтичне, драматичне, комічне й ін.). Хореографу варто також бути обережним з використанням для спортивних композицій музичних фрагментів з балетних вистав, де композитор створює образ філософського звучання.

\section{СПИСОК БІБЛІОГРАФІЧНИХ ПОСИЛАНЬ}

Абсалямова, И. В. (1983). Совершенствование техники фигурного катания на коньках (спортивные танцы на льду). ГЦОЛИФК.

Медведева, И. М. (2002). Система подготовки спортсменов в фигурном катании на коньках. Олимпийская литература.

Медведєва, I. М. (2014). Тенденції розвитку фігурного катання на ковзанах у світі. Вісник Чернігівського національного педагогічного університету. Серія: Педагогічні науки. Фізичне виховання та спорт, 118(4), 115-117.

Помелова, М. П., \& Тихомиров, А. К. (1985). История фигурного катания на коньках. Московский областной государственный институт физической культуры.

Прес-служба відділення НОК України в Одеській області. (2019, 25 лютого). Цей день в історії. 25 років тому одеська фігуристка Оксана Баюл стала олімпійською чемпіонкою! Відділення Національного олімпійського комітету України в Одеській області. https://noc-odessa.org.ua/novyny/novyny/377-25-rokiv-nazad-oksana-bayulstala-olimpiiskoiu-chempionkoiu-video.html?fb_comment_id=2216303651753019_2218 057978244253.

Рыжкин, В. И. (1970). Танцы на льду. Физкультура и спорт.

Ситченко, К. В. (2018). Хореографічна підготовка як основа успішного виступу виконавців спортивних танців на льоду. Українська культура: минуле, сучасне, шляхи розвитку, 28, 272-276. 
Тихонов, В. П. (Сост.). (1985). Основы хореографической подготовки фигуристов. Главное управление научно-методической работы.

Тодорова, В. (2018). Теоретико-методичні основи хореографічної підготовки в техніко-естетичних видах спорту (на матеріалі спортивної аеробіки). ЛДУФК.

Український Форпост Спорту. (2017, 4 лютого). Золотий виступ Олександри Назарової та Максима Нікітіна на Універсіаді 2017 [Відео]. YouTube. https:/www.youtube.com/ watch?v=2q-ZXV5Wtt8.

\section{REFERENCES}

Absalyamova, I. V. (1983). Sovershenstvovanie tekhniki figurnogo kataniya na kon'kakh (sportivnye tantsy na l'du) [Improving the Technique of Figure Skating (Ice Dancing)]. SCOLIPE [in Russian].

Medvedieva, I. M. (2002). Sistema podgotovki sportsmenov v figurnom katanii na kon'kakh [The System of Training Athletes in Figure Skating]. Olimpiiskaya Literatura [in Russian].

Medvedieva, I. M. (2014). Tendentsii rozvytku fihurnoho katannia na kovzanakh u sviti [Trends in the Development of Figure Skating in the World]. Bulletin of the Chernihiv National Pedagogical University. Series: Pedagogical Sciences. Physical Education and Sports, 118(4), 115-117 [in Ukrainian].

Pomelova, M. P., \& Tikhomirov, A. K. (1985). Istoriia figurnogo kataniia na konkakh [The History of Figure Skating]. Moscow Regional State Institute of Physical Education [in Russian].

Pres-Sluzhba Viddilennia NOK Ukrainy v Odeskii Oblasti. (2019, February 25). Tsei den v istorii. 25 rokiv tomu odeska fihurystka Oksana Baiul stala olimpiiskoiu chempionkoiu! [This Day in History. 25 Years Ago Odessa Figure Skater Oksana Baiul Became an Olympic Champion!]. Branch of the National Olympic Committee of Ukraine in Odessa Region. https://nocodessa.org.ua/novyny/novyny/377-25-rokiv-nazad-oksana-bayul-stala-olimpiiskoiuchempionkoiu-video.html?fb_comment_id=2216303651753019_2218057978244253 [in Ukrainian].

Ryzhkin, V. I. (1970). Tantcy na Ldu [Dancing on Ice]. Fizkultura i Sport [in Russian].

Sytchenko, K.V. (2018). Khoreohrafichna pidhotovka yak osnova uspishnoho vystupu vykonavtsiv sportyvnykh tantsiv na lodu [Choreographic Composition of Performance Exhibitors of Sport Dances on Ice]. Ukrainian Culture: Past, Modern and Ways of Development, 28, 272276 [in Ukrainian].

Tikhonov, V. P. (Comp.). (1985). Osnovy khoreograficheskoi podgotovki figuristov [The Basics of the Choreographic Training of Figure Skaters]. Glavnoe Upravlenie Nauchno-Metodicheskoi Raboty [in Russian].

Todorova, V. (2018). Teoretyko-metodychni osnovy khoreohrafichnoi pidhotovky $v$ tekhnikoestetychnykh vydakh sportu (na materiali sportyvnoi aerobiky) [Theoretical and Methodological Foundations of Choreographic Training in Technical and Aesthetic Sports (on the Material of Sports Aerobics)]. Lviv State University of Physical Culture [in Ukrainian].

Ukrainskyi Forpost Sportu. (2017, February 4). Zolotyi vystup Oleksandry Nazarovoi ta Maksyma Nikitina na Universiadi 2017 [Golden Performance of Oleksandra Nazarova and Maksym Nikitin at the 2017 Universiade] [Video]. YouTube. https://www.youtube.com/watch?v=2qZXV5Wtt8. 